\title{
7
}

\section{Muslim Identity, Psychic Detachment and Universal Rights}

Rumy Hasan

\section{Tensions between Muslim identity and European citizenship}

In his letter of 19 January 2015 to 1,000 mosque leaders, UK Communities Secretary Eric Pickles asked how faith in Islam can be part of British identity (DCLG 2015). This was an implicit recognition that there is a tension between being Muslim and British; moreover, it was an acknowledgement by Mr Pickles and his government that there is lack of integration of Britain's Muslim communities. Similar sentiments are doubtless widespread in Europe so it is unarguably the case that the situation of Muslims in the EU has become a major issue for policy makers and for society at large.

Whilst addressing the radicalisation of Muslims is now of the highest priority, there are wider, societal, concerns about Muslims in Europe, which are deep-rooted. In France, an opinion conducted by IFOP in October 2012 found that 60 per cent of respondents consider that the influence and visibility of Islam in France are too high, and that 43 per cent of French believe that the presence of a Muslim community in France is a threat to the French identity, whilst only 17 per cent consider this is a source of enrichment (IFOP 2012).

In Germany (which has, after France, the second largest Muslim population in the EU), there have since October 2014 been regular and substantial anti-Islam marches and rallies (especially in the city of Dresden) organised by a newly-formed grassroots movement by the name of PEGIDA (Patriotic Europeans against the Islamisation of the West). Though the rise of this group was sudden and surprising, the potential support for its views is, in fact, very strong. This is attested by a survey by the Bertelsmann Foundation in January 2015 which 
found that 57 per cent of Germans considered Islam "very much" or "somewhat" of a threat and that 61 per cent believe that Islam is "incompatible with the western world" (Bertelsmann Stiftung 2015). Similar marches have taken place in Norway, Denmark, the Czech Republic, Austria, and the UK.

In the Netherlands, long renowned for its tolerance and liberalism, the anti-Islam Partij voor de Vrijheid (PVV) - 'Party for Freedom' - led by the controversial Geert Wilders came third in the elections to the EU parliament in May 2014 and, by late 2014, was leading in the polls. Again, this ought not to be unduly surprising given that concerns about Islam have existed for a considerable period. For example, a survey conducted by Paul Sniderman and Louk Hagendoorn as far back as 1998, that is before 9/11 and the 'War on Terror', showed that approximately half the Dutch population thought that "Western European and Muslim ways of life are irreconcilable" (Sniderman and Hagendoorn 2007: 22). ${ }^{1}$

In Britain too, there has been rising unease about Islam. This is evidenced by the British Social Attitudes Survey of 2010, which highlighted the fact that of all the major religions in Britain, only Islam generated an overall negative response (Voas and Ling 2010). Similarly, a Populus opinion poll in 2011, considered the largest survey into identity and extremism in the UK, found that 52 per cent of respondents agreed with the proposition that "Muslims create problems in the UK" (a far higher percentage than for other religious groups) (Populus 2011). Indeed, such negative responses are likely to have increased during the intervening years given recent troubling phenomena. These include the 'Trojan Horse' plot in Birmingham whereby hard-line Islamists were attempting to take over the running of a number of state schools in areas which are almost entirely comprised of Muslim neighbourhoods; the scandal of the 'grooming' and child sexual exploitation of white girls by gangs of men from a Pakistani Muslim background in several towns and cities (in Bristol the perpetrators were Somali men); the killing by Islamists of the soldier Lee Rigby in Woolwich, London, in May 2013; the fact that many British Muslims have joined the jihadist group Islamic State; and various terror threats that have been thwarted. All these incidents will inevitably increase the negative views about Islam and Muslims.

In the aftermath of the Charlie Hebdo massacre, the leader of UKIP Nigel Farage asserted during an EU parliamentary debate on 12 January 2015, on the terror attacks in Paris, that "mass immigration had made it frankly impossible for many new communities to integrate. We do have, I'm afraid, I'm sad to say, a fifth column that is living within our own countries, that is utterly opposed to our values" (BBC News 2015). It is 
unambiguous that the 'fifth column' that Mr Farage was referring to are radicalised Muslims.

Even Eurosceptic parties such as UKIP are in agreement that migrants especially from outside of the EU (a large percentage of whom are Muslim) ought to be integrated into mainstream European societies, adhering to core universal values, including democracy, freedom of expression, and equality of women and gays.

\section{UK and other EU countries: different approaches, similar outcomes}

The UK approach regarding immigrants that has long been adhered to by both Conservative and Labour governments, albeit without systematic design, has been that of 'multiculturalism'. As a result, a non-interventionist, laissez-faire principle has been adopted whereby migrants can lead lives pretty much akin to those obtaining in their countries of origin. This has been backed up with resources and legal provisions. This being the case, there has been little attention paid to the integration of migrants. Moreover, since the early 2000s, all the three major parties have described Britain as being a 'multifaith' society. In a report by the Department of Communities and Local Government, published in 2008, entitled Face to Face and Side by Side, the subtitle makes explicit its understanding of British society: A framework for partnership in our multi faith society. Investment was set aside to bring together "faith groups" in "partnership" to deliver local services via the creation of a new local "Faiths in Action fund" and "Regional Faith Forums". Indeed, the Coalition government of 2010-15 gave this view the imprimatur of a Minister for Faith and Communities - the first government to create such a ministerial post. There is, however, a widespread feeling that such an approach has not been successful, particularly in regard to Muslims indeed the UK Prime Minister David Cameron, in a speech in Munich in February 2011, acknowledged this by stating that "state multiculturalism had failed" (BBC News 2011). Yet, government policies have not to any appreciable extent altered from a multiculturalist, multifaith, stance, as attested by its commitment to faith schools and faith-based free schools and academies.

A similar approach to that of Britain has been adopted by the Netherlands and Scandinavian countries. As in Britain, the demands made by Muslim settlers for separate provisions and exemptions to the law is generating considerable disquiet to the point of hostility. Unlike Britain, however, there has, in recent years, been greater emphasis in 
the Nordic countries and the Netherlands on integration; buttressed by the appointment of Ministers for Integration. By contrast, Germany had long regarded its immigrant population, especially Turkish Muslims, as temporary 'guest-workers' and not as permanent settlers and citizens. But recognising that they were not returning home, a multicultural approach also took root in Germany and, as elsewhere, generated problems which led Chancellor Angela Merkel, in October 2010, to explicitly state that attempts to build a multicultural society in Germany have "utterly failed" (BBC News 2010); precisely the same sentiment that is now so prevalent in Britain and the Netherlands.

France, by contrast, rejected multiculturalism in favour of a republican model that is opposed to separate religious and cultural identities. But there was very little emphasis in integrating migrants; rather the reality has been of a de facto multiculturalist, separatist, dynamic augmented by the establishment of deprived housing estates for migrants - the banlieue - on the periphery of its town and cities. This was acknowledged by Prime Minister Manuel Valls in a speech in Paris on 20 January 2015 when he asserted that "the country's recent terrorist attacks have exposed a 'geographic, social, ethnic apartheid' present in society" (EuroNews 2015).

Therefore, notwithstanding the fact of differences in approaches, the resultant outcome - albeit to varying degrees - is undeniable, that is, there has arisen widespread segregation and ghettoisation in towns and cities in several EU countries with large religious and ethnic minority communities, especially of Muslims. Rather than a new respectful, tolerant, all-encompassing, socially-cohesive, society, we see evidence of segregation, ghettoisation, resentment, alienation, communal stress, and the leading of what Ted Cantle (2006: 4) has termed "parallel lives". My argument is that some religious-ethnic communities have become 'psychically detached' from mainstream society; the core determinant of which is a powerful religious identity and it is arguably the case that this is most salient for Muslims. ${ }^{2}$ Evidence suggests that there is a conflict between Muslim identity and universal rights and values.

\section{Utilising the conceptual device of 'psychic detachment'}

Hitherto, in academic thinking, problems relating to the lack (or even absence) of integration of very large numbers of religious-ethnic minority communities have been considered to be the result of institutionalised racism and a racist discourse writ large (see for example Parekh 2000a; 
Vasta 2007). These can be deemed the 'constraint' factors that religiousethnic minority migrants have encountered and which have led to their segregation in certain localities of towns and cities among those of a similar background (Lakey 1997). Policy prescriptions flowing from this view lead to correcting for racism and racist discourse in society, augmented by the implementation of anti-discriminatory legislation. It is argued that with the removal of these severe constraints, integration can proceed apace.

My hypothesis is that the constraint factors are no longer dominant in the UK: on the contrary, 'choice' factors (where religious-minority communities 'choose' to live and associate among their own) have now become a key determinant of segregation and low levels of integration for at least some religious-ethnic minorities, especially many Muslims.

What does it mean to say that a group of persons (for our purposes here, significant numbers of Muslims) is 'psychically detached' from the society in which they live? ${ }^{3}$ At its extreme it can be seen as immigrants' mode of thinking, belonging, living, as being rooted elsewhere: that is, their alienation from the host society is such that they might as well be living in another land. In turn, this engenders alienation among a very significant percentage of the host population. A strong definition is one where there are no points of contact between the group in question and the rest of society, including negligible contact with those from other ethnic minority communities. In essence, therefore, 'detachment' is the obverse of 'integration'. We postulate the following three phenomena as being the necessary and sufficient conditions for psychic detachment (Hasan 2010: 100-3):

1) Normative detachment: where values, beliefs, and attendant practices are profoundly different to those of the majority society;

2) Social detachment: where there is a lack of inter-personal 'points of contact' with those not from the same religious-ethnic community;

3) Disidentification: where there is very low or zero identification with the host society (Verkuyten and Yildiz 2007).

We further hypothesise that these conditions arise with great intensity in sharply-segregated areas. A corollary to this is 'socio-economic' - or 'structural' - detachment. This frequently occurs in segregated communities where there has been industrial decline - so that workplaces that employed people of various backgrounds no longer exist, thereby leaving communities economically marooned, that is, socio-economically 
detached. However, in our definition, this is not essential to psychic detachment: a member of a religious-ethnic minority may work with colleagues from other backgrounds but still exhibit high levels of psychic detachment if the other three conditions are met.

The fundamental argument is that a strong religious identity compounded by in-group pressure (self-exclusion) leads to the intensification of psychic detachment (in each of the three constituent parts indicated). Such a simple model suggests a mediating process (religious identity) between out-group reactions (e.g. unease, hostility) and in-group reactions (internal pressures, self-exclusion). The presumption is that the higher the levels of psychic detachment of a group (in this instance, Muslims), the greater the alienation felt by significant numbers of the majority society. Polling evidence highlighted above certainly posits this as a persuasive explanation.

A related hypothesis is that religion strongly moulds the community identity of Muslims, so that there is a high level of self-perception in religious terms, that is to say the faith becomes a de facto ethnic marker. This is in sharp contrast to the largely-secular indigenous white society in Britain and indeed throughout Europe - including in the more religious Mediterranean countries. We further hypothesise that the formation of a strong religious identity and attendant psychic detachment is directly linked to the formation of segregated communities; in turn, this impacts upon the welfare and prosperity of citizens within these communities. A key outcome is the strong reliance on the "social and cultural capital" (Bourdieu and Passeron 1990) of a religious-ethnic community that becomes the vital conduit for "economic capital", survival, and reproduction. A reinforcing mechanism arises: religion $\rightarrow$ identity $\rightarrow$ community $\rightarrow$ cultural capital $\rightarrow$ economic and social capital $\rightarrow$ intensification of religious identity $\rightarrow$ psychic detachment $\rightarrow$ religion $\rightarrow$ identity $\rightarrow$ etc.

A key element is the impact of education on psychic detachment and the extent to which schools contribute towards the socialisation of their pupils into a religious (for our purposes, Muslim) identity. In regard to the latter, there appears to be an increase in demand for Muslim faith schools; a natural expression of heightened Islamic identity. The key question here is whether these schools systematically socialise youths into an Islamic identity and, therefore, greatly contribute to psychic detachment. If this is indeed the case, then it follows that governments' aim of increasing integration and social cohesion is not likely to be served well by religious schools.

No matter their political hue, British Governments have, for decades, been reluctant to map out a path towards an agreed national 
identity - at least until recent years when some importance has been put on improving social or community cohesion and attention paid to factors that are deemed to comprise 'Britishness'.

In stark contrast, community and religious 'leaders' and 'elders' from some religious-ethnic minority groups have been very clear as to where they want to get to: the granting of resources, rights, separate laws, and exemptions to the law for their respective 'communities'. Muslim organisations have been assertive in making these demands. For example, the Islamic Sharia Council wishes for the principles of sharia to be eventually recognised in English law as in the following statement:

Though the Council is not yet legally recognised by the authorities in the UK, the fact that it is already established, and is gradually gaining ground among the Muslim community, and the satisfaction attained by those who seek its ruling, are all preparatory steps towards the final goal of gaining the confidence of the host community in the soundness of the Islamic legal system and the help and insight they could gain from it (Islamic Sharia Council 2016).

In a similar vein, the Muslim Action Forum (MAF) is attempting to bring about a de facto blasphemy law. A press release on 8 February 2015 made this clear:

MAF intends to launch a series of legal challenges in the English Court system to establish that such depictions of our Holy Prophet peace be upon Him is the worst kind of 'Hate Crime' that can be perpetrated on the 3 million Muslims in the UK and 1.7 billion Muslims worldwide. We shall support this strategy through amendment of some existing legislation and the presentation of a Private Members Bill that promotes the idea of Global Civility (MAF 2015).

So far these demands have been resisted by the Government and do not have traction in wider society. But this endeavour has greatly been assisted by the academy whose theories and ideas have coalesced under the rubric of multiculturalism. Unwittingly and aimlessly, this came to be adopted by national and local governments and which has engendered and intensified a separatist dynamic. Indeed what has arisen in towns and cities across the country are ghettoised monocultural and monofaith neighbourhoods where mixing with those not of the same religious-ethnic group is minimal or practically non-existent. A particularly disturbing aspect of this is the segregation of schools so that large 
numbers of children from 'faith communities' are marooned from the majority white society and indeed also from other ethnic groups.

The salutary goal of social cohesion requires a concerted inclusiveness into mainstream society, in both mental and material terms. But what is also of vital importance is the acknowledgment that a gradual withering away of 'faith identities' will enormously aid the cause of social justice, integration, and cohesion. Such a strong claim is based on the rapidly declining role of religion in society and the fact that religious identity is largely irrelevant to the majority white population. In the UK, with the exception of Northern Ireland and pockets of Scotland, the epithets 'Protestant' or 'Catholic' as descriptors of identity have long gone into desuetude. Public policy, above all in regard to school education, can significantly rein in the artificial division engendered by religion, a task that is made inordinately easier as a consequence of the relentless decline in religious belief in Western societies (though significantly less so in the US) so that religious identity has become largely irrelevant to the mass of the population. Northern Ireland's sectarian divisions are a sobering reminder of the path that must be avoided.

The most common objection to such reasoning is that communities have the right to identify themselves with a culture and religion, which ought to be acknowledged by the national and local government, and wider society. Moreover, this needs to be buttressed by the allocation of funds, resources, and legal provisions. The rejoinder to this view is that people do indeed have the right to identify themselves whichever way they want. But it is not so obvious that people have a right to act on chosen identities whose precepts conflict with human rights, or that create major problems for society as a whole. What experience has clearly shown is that cultural and faith identities tend to be divisive and not at all conducive to social cohesion. Importantly, separate rights, laws and exemptions to the laws - in other words legal pluralism - inevitably lead to the breach of universalism and equality before the law.

Multiculturalists argue that this should be permissible as the principle of equality in law is problematic given that it can prohibit certain religious customs and practices. Ipso facto, it is tantamount to being discriminatory. This paradoxical reasoning has been acknowledged by the courts as in the famous example of the case Mandla v. Dowell Lee [Mandla 1983]. The House of Lords accepted that it was wrong for a school to impose a school uniform policy for all its pupils (the school in question had prohibited the wearing of Sikh turbans on the grounds that this was a breach of its school uniform policy). In other words, equal treatment for all the boys in the school was deemed to be discriminatory against 
those of the Sikh faith, a key requirement of which is for boys and men to wear a turban. Similar reasoning applied to the granting of an exemption to Sikhs from wearing a helmet on motor cycles and on building sites. Other examples of exemptions on the basis of religion include Muslim girls being allowed to wear the hijab in schools, Jewish boys the skull cap, Sikh girls a religious bangle; and religious slaughter of animals without pre-stunning is granted to Jewish and Muslim abattoirs.

But not all exemptions are provided on religious grounds. For example, Sikhs are often prevented from carrying a dagger (kirpan); Muslims girls and women are forbidden from undergoing clitoridectomy (female genital mutilation), Shia Muslims from self-flagellation during their Ashura ceremony. There is no clear operative principle in regard to where exemptions on religious grounds are granted and where they are not. It seems that if political lobbying is strong enough, governments will authorise exemptions.

By comparison, exemptions on non-religious grounds are rarely granted. Suppose that at a school, there is a school uniform policy, but exemptions are granted for Jewish, Muslim, and Sikh children. Suppose also that some children closely follow the local football team as part of a long-standing family and community tradition. Accordingly, they wish to wear the club's shirt to school, and so also be granted exemption from the standard school uniform. If the school insists on maintaining its policy on uniforms (let us not be detracted here about the merits and demerits of school uniforms, or indeed of uniforms in general), it can only refuse the exemption with respect to football shirts on the grounds that an identity based on allegiance to a football club is less than an identity based on religion. Such a differential standard is likely to generate an alienating and divisive dynamic that can generate increased hostility by the sections of the majority society to religious minorities. It is indubitably the case that significant sections of the majority may not readily understand, or approve, of the normative basis for this decision when it is blatantly unequal.

\section{The attempt by OIC countries to subvert universal rights}

As already stressed, separate laws on the basis of culture and religion imply the dilution or rejection of universal human rights. This is not ordinarily of concern to Muslim-majority countries where governments do not significantly veer away from core Islamic doctrines and are either sympathetic or do not wish to alienate religious authorities. So any right or law that infringes Islamic beliefs or practices is impermissible, 
although there are of course variations between countries in strictness of application. But these countries also desire to extend such an approach to the international arena. This is precisely what has been happening at the UN regarding the Universal Declaration of Human Rights (UDHR) passed in 1948; it is important to note that this seminal declaration was supported in full by all Islamic countries with the exception of Saudi Arabia. However, the fifty-seven-nation OIC (Organisation of the Islamic Conference) has been attempting to subvert this. ${ }^{4}$

In 1990 the OIC adopted the Cairo Declaration of Human Rights in Islam whose concluding articles (24 and 25) stipulate "All the rights and freedoms stipulated in this Declaration are subject to the Islamic Shari'ah" and "The Islamic Shari'ah is the only source of reference for the explanation or clarification of any of the articles of the Declaration" (OIC 1990). At the 1993 World Conference on Human Rights in Vienna, Islamic States pressed for the acceptance of the Cairo Declaration as an alternative to the Universal Declaration of Human Rights (IHEU 2008). Its later efforts have been to try and have passed a non-binding resolution against the defamation of religion. But none of these attempts have, hitherto, succeeded. On Human Rights Day, 10 December 2007, the Ambassador of Pakistan, addressing the Human Rights Council on behalf of the OIC claimed that the Cairo Declaration "is not an alternative, competing worldview on human rights. It complements the Universal Declaration as it addresses religious and cultural specificity of the Muslim countries" (IHEU 2008). So far, the majority of countries reject this reasoning and, therefore, the $U D H R$ remains intact.

The OIC has a problem with at least two articles (18 and 19), which directly conflict with sharia law in all its variants:

Article 18: Everyone has the right to freedom of thought, conscience and religion; this right includes freedom to change his religion or belief, and freedom, either alone or in community with others and in public or private, to manifest his religion or belief in teaching, practice, worship and observance;

Article 19: Everyone has the right to freedom of opinion and expression; this right includes freedom to hold opinions without interference and to seek, receive and impart information and ideas through any media and regardless of frontiers (UNOHCR 1948).

What the OIC is arguing is that criticism of religion is defamatory and is akin to racism - conflating ideas/ideology with people. That is to say, religious people are hurt by criticism, thereby are not accorded due respect 
and recognition. This is deemed to be equivalent to physical harm. In essence, the OIC is applying and extending multicultural, multifaith thinking to the global arena. They are in fact demanding privileges for religious beliefs and practices that are buttressed by stringent legislation. This runs firmly against egalitarian universalism which advocates universal human rights and equality before the law; the central tenet of the UDHR. Accordingly, it disallows privileges on the grounds of culture and religion - which is the essence of multiculturalism and multifaithism.

If the OIC managed to achieve the dilution of the UDHR, this will inevitably give confidence to Muslim groups in Britain (and indeed in western countries generally) such as the Islamic Sharia Council and Muslim Action Forum to lobby with greater vigour. This will indubitably be a setback for the further integration of Muslims into mainstream society.

What this discussion points to is straightforward: the foundational principle of an integrated, cohesive society that is based on justice and egalitarianism must be the advocacy of universal rights (sometimes referred to as one law for all). This sends out a powerful signal that governments are sincere and determined in attempting to build society on the basis of common citizenship and social justice, thereby casting aside the emphasis on 'difference' that has had such a corrosive, divisive, effect. Indeed, we can make the case that integration and social cohesion are improved the more religion and religious identity are confined to the private sphere. From this secular republican perspective, based on egalitarian universalism, the social equality of religion or belief approach is necessarily sub-optimal in that it is likely to entrench religious identity and exemptions on grounds of religion, which we argue run counter to the overarching societal goal of a more cohesive society. There is also the question of democracy. The privileges afforded to religions appear to run against the wishes of the majority in Britain. A poll conducted in November 2014 for the Huffington Post, for example, "reveals that just $8 \%$ of Britons describe themselves as very religious, with more than $60 \%$ saying they were not religious at all; and of the 'non-religious' people polled, more than $60 \%$ said they thought religion caused more problems than it solved" (Elgot 2014).

\section{Concluding remarks}

The crux of the matter regarding Muslim identity is that Islam is a very demanding religion that encompasses every aspect of life, from birth 
till death. Hence, there is no separation between the public and private spheres or between religious and secular domains. To fully comply with Islamic sharia law necessarily conflicts with the notion of universal rights and secular values; this is precisely the stance of OIC countries. In 2008, this was also recognised by Britain's highest court concerning a case in which the government attempted to remove a woman and child to Lebanon. In a 5-0 ruling the Law Lords argued "that there was no place in sharia for the equal treatment of the sexes. It would be a 'flagrant breach' of the European Convention on Human Rights for the Government to remove a woman to Lebanon, where she would lose custody of her son because of sharia-inspired family law" (Verkaik 2008).

From this perspective, the social equality of religion or belief is problematic as some religions, notably Islam, demand more than equality before the law, that is to say, not just protection under the law but legal privileges. In the Introduction (22-3), attention is drawn to the exemptions on religious grounds to the extent that these "carve out an area in which normal equalities laws do not apply ... [and which] are extraordinary provisions to find in the law of any country". This is the inevitable outcome of a country deemed to be 'multifaith'. To comply with just the civil laws under Islam (demands for sharia-compliant criminal laws are rarely called for by mainstream Muslim organisations in the West) does indeed require myriad 'extraordinary provisions'.

In the interests of social cohesion and better integration of Muslims in mainstream western societies, both the Government and wider society must resist demands for such privileges, not least because they are alienating to the largely irreligious and secular majority society. That said, we can surmise that most mainstream Muslims in Europe are content not to fulfil all of Islam's burdensome obligations and so will refrain from making inordinate demands for exemptions. In time, one hopes for the prospect of their acceding to the principle of equality before the law and - even in a self-styled multifaith society - acceptance of its secular nature.

The task for policy makers in Britain and other European countries, which is now of considerable urgency and importance, is how to reverse the processes of separatism identified above. These have reached worrisome proportions, to the point of outright rejection of European society, with correspondingly high levels of psychic detachment, and generated considerable unease in all EU countries with significant Muslim populations. The overall objective, from this perspective, is to reduce psychic detachment so that universal rights, laws and values are internalised and trump the narrow Muslim identity that has become so prevalent. 
The benefits of this are self-evident and significant, especially for future generations. It is not apparent that the social equality of religion approach can meet this formidable challenge.

\section{Notes}

1. Some of the reasons for this irreconcilability include "nine out of every ten agree that Muslim men in the Netherlands dominate their women... Three out of every four Dutch agree that Muslims in the Netherlands raise their children in an authoritarian way" (Sniderman and Hagendoorn 2007: 23).

2. This argument was first developed in Hasan (2010, Ch. 3).

3 . Note that psychic detachment is rather distinct from that of the well-researched phenomenon of 'social exclusion', which arises in the absence of integration in the labour market (see, for example, Levitas 1996; Blanc 1998).

4. The OIC was formed by Saudi Arabia in 1969, and is funded by it. It is now known as the Organisation of Islamic Cooperation. 